\title{
地域地盤地質情報に対する地盤エ学データベース・システムの開発と構築理念
}

\author{
岩崎 好規**・諏訪 靖二**・山本 浩司**
}

\section{Concept and Development of Geotechnical Data Base System for Regional Ground and Geological Information*}

\author{
Yoshinori IWASAKI**, Seiji SUWA** and Kouji YAMAMOTO**
}

\begin{abstract}
The computerization, which has made affordable to handle abundant data by a Personal Computer ( PC ), is now expanding its usage for several organizations to introduce geological ground data base system using such information as geological boring log.

The Geo-Research Institute, Osaka Soil Test Lab., has developed the geotechnical data base system for regional ground and geological information which is characterized as follows ;

(1) To handle general geology ranging very soft soil condition to rock ground.

(2) To accept not only boring log information but also basic results of physical and mechanical results obtained by laboratory tests.

(3) To construct relational data base to establish effective and easy data handling system to analyse regional characteristics by comparison and extraction.

(4) To introduce hard independent environment to have more freedom under the present situation of the rapid change of the hard-ware system itself.

(5) To develope a local system ( rather PC level of computer) for inputing data, in addition to a host system ( the larger sized computer) for handling the whole integrated information to obtain effective combination of various level of available computer resources.

The paper describes the general concept of the geotechnical data base system developed in Geo-Research Inst., and shows some results of regional ground characteristics in Osaka area as an example of output of thesystem developed.
\end{abstract}

KEY WORDS : Data Base, Regional Ground, Geological Information, Boring

\section{1. はじめに}

21 世紀への屝が開かれようとする今, コンピュータと通 信処理技術の融合がもたらした取り扱う情報量の拡大化に よる情報の質的変化は, 我々の社会生活に新たなる付加価 值を与えようとしている．建設の分野に㧊いても，建設プ ロジェクトの各段階での意志決定などにおいて，これらの 巨大化した情報を使いこなすことが重要な課題となりつつ ある。

さて, 高度情報化における情報技術を支える要素に, デー タベースがある. データベース（DB：Data Base ) とは, 情報基地の意であり，いわゆる戦略用語としての意味合い が強い，DB自体は，コンピュータの能力を活用して様々

* 日本地質学会第 97 年討論会 ( 1990 年, 横浜 ) で一部講演 ** 財) 大阪土質試験所 Osaka Soil Test Lab., 3-1-23 NishiHonmachi, Nishi-ku, Osaka 550, Japan
な利用者が種々のデータを共同で利用できるように工夫し た共用ファイルとして定義されるが，一般には，システム をも含めて広義の意味で “データベース”之言う場合が多 い. 建設の分野においても, 数種のDBが構筑されており, 既に情報提供を開始した例もある（日本建設情報総合セン ター, 1989 ). しかしながら，その半数は文献抄録など の二次情報を提供する文献DBであり, 詳細な情報を得たい とする要求から地盤調査で得られる生の試験值のような一 次情報を扱うファクトDBの構筑が望まれる状況にある。そ のファクトDBの一つに, 地盤情報DBがある，地盤情報に は, 地盤調查試験, 地形, 地下水位, 地盤変動, 地下 構築物など種々の情報があるが, 現時点では, 主に地盤調 查情報のデータベース化が進められている. 地船情報DB構 築の試みは 1970 年代初頭に始まり（幾志・菅原・清水, 1971 ), その後, コンピュータ技術の発達とともに数多く の構築が進められ, 最近では数例が実用化の域に達してい 
る (石井， 1985 ; 石村・中山，1986)。しかし，それ らの多くは土質柱状図を主体としたDBであり，建設全般へ の利用を目的とした構筑はほとんどなされていない．

そこで，著者らは，建設全般への利用を目指して超軟弱 な地盤から岩盤までの地盤調查（ボーリング調査）データ を対象とした地盤情報DBシステムの開発を行ってきた(岩 崎・諏訪・山本，1989)。本文では，当システムの開発 に際して重視したDBの構築理念について言及した上で, 地 盤調査試験DBシステムの概要と応用例について述べる.

\section{2. 地盤情報とデータベース化の意義}

地盤調査は，構造物の建設を目的として実施されること がほとんどである，そのことから，地盤情報は『調查一計 画一設計一施工一維持』の流れの中で，まずその役割を果 たすことになる，すなわち，調査・計画の段階に扔いて地 盤情報は，既存の構造物情報，その施工例・失敗例・計測 例に関する情報，気象等の自然条件情報などと並列に位置 する基礎情報として扱われる。 そして，設計の段階では， 基準設計法，汎用設計法，研究レベルの設計法を適用する 際の設計モデル地盤に形を変え，さらに施工の段階では， 施工法や現場計測工法の決定を行うための情報となる。よっ て, 建設の各段階で要求される地盤情報の領域は常に変化 し，加えて構造物の種類や設計法によっても必要とされる 地盤情報の質と量は同一でない.

一方, 都市計画, 地盤の研究, 行政面などにおいては, 地盤（調查）情報を総て必要とするわけではなく，その 利用は二次的であると言える。例えば，液状化の検討には， 地層，地下水位， $N$ 值， $D_{50}$ 程度の情報があれば設計基準 に基づいた検討は十分に可能である。

第 1 図に，地盤調查情報の流れとDBの用途について前 述の内容ををとめた。構築中のものも含め現状の地盤情報 DBは, 都市計画や地盤の研究への運用に重点を置いたもの がほとんどで，地盤情報の二次的な活用において成果をあ げてきた，例えば，地盤の研究では，東京都総合地盤図， 新編大阪地盤図, 最新名古屋地盤図などが地盤情報DBを中 核とした研究によって作成されている，都市計画では，大 阪市域の液状化検討・耐震検討 (柴田・岩崎・䯅訪・山本, 1987 ；吉川・岩崎・田居，1987），東京都の液状化予測 （東京都土木技術研究所，1987）など，地盤情報DBを 用いて防災計画に関わる検討が数多く実施されている。こ れらはともに，大量の地盤情報をもって新たな地盤工学的 価值を見いだそうとする試みであって，その点において現 状の地盤情報DBが果たした役割は大きいと考えられる.

しかしながら, 昨今のコンピュータ技術の革新, 人工知 能（AI : Artificial Intelligence）に代表されるコンピュー 夕の新しい利用技術の出現は, 21 世紀へ向けて地盤工学さ

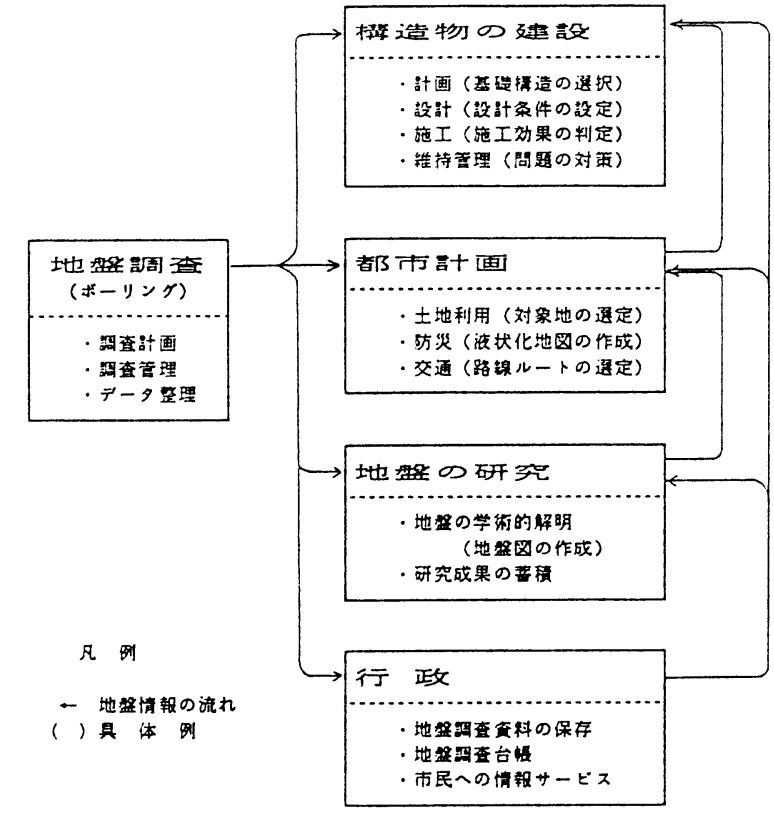

第 1 図地盤調査情報の流れとデータベースの用途

らには建設分野全体に対しても新たな技術展開を生み出そ うとしている。 そのような現状にあって，これまで地盤情 報DBがあまり活用されなかった分野，つまり構造物の建設 といら地盤調查本来の目的への運用が今後予想され，現在 すでに実用化が進む設計支援システムや，将来実現するか もしれないAIを応用したエキスパート・システム ( Expert System )による自動設計システムとの連結を考慮した地盤 情報DBの構築が必要と考えられる，これらに，要求され る情報は，緻密であり，かつ幅広く，現状の地盤情報DB では対応が難しい，また，これらのシステム実現の是非に かかわらず，国民の資産である地盤（調査）情報を綿密 に調查報告書を再現できるまでのレベルで高度にデータベー ス化することは，将来，財政の効率的運用が要求される社 会情勢の中では，社会資本の蓄積に有用であり，新たな空 間（例えば，海空間，地下空間）の利用を計る上でも貴 重な基礎資料として役立つと考えられる。

以上のことから，地盤情報をデータベース化する意義は 大きいと考えられ，その利用価値を高めるためにも多種の 地盤情報を詳細にデータベース化することが，地盤情報DB の構築理念としてまず重視すべき点と考えられる.

\section{3. 地盤調查情報のデータベース化}

\section{1 データベース化の現状と課題}

現状の地盤情報DBは，主にボーリング調査の情報をデー タベ一ス化（以下，地盤調查試騃DBと称す）している（諏 訪・山本嘉・山本浩他, 1987 ；風間・岩崎・堀井, 1989). 公表された地盤調査試験DBは，まず扱う情報の種類（量） で大きく 2 分される。ひとつは，ボーリング柱状図（地 
層, N值)を主体としたデータベース化を行っているグルー プで, 土質試験データを扱う場合は一覧表の結果 (代表值) 程度に留めている，もうひとつは，柱状図はもとより土質 試験データの詳細（試験值）に至るまでのデータベース化 を行っているグループである. 前者は, 陸域部を対象とし たDBをはじめとして, ほとんどのDBの方式となっている. 後者は，海域部を対象としたDBに数例見られ，著者の一 人が以前から取り組んできた方式である（諏訪・山本・池 森, 1980 ).

また， システムの構成についても 2 つの指向がある. ひとつは, 大型汎用コンピュータを用いたもの，もうひと つは，パーソナルコンピュータ（以下，パソコンと称す） を用いたものである. 前者は, DBを管理するシステム(DBMS :

Data Base Management System ）に汎用DBMSを用いる 場合がほとんどであり, 実用化された地盤調査試験DBの主 流をなす，後者は, 近年のパソコン機能（演算速度, 記 憶容量, 外部記憶補助装置 ) の急速な発展とともに構築が 始まったもので, 狭い地域を対象としたものに多く, DBMS は独自に開発される場合が多いが, 用途を限れば汎用DBMS を利用することも可能である (山本浩・諏訪・山本嘉, 1987).

この様に, 地盤調査試験DBの構築に関する現状は必ずし も統制されていない. DBのあり方としては, 日時・場所 を問わず末端の利用者（専門家に限らず一般人も）にあら ゆる情報を提供でき, 将来的にも永続するシステムである ことが理想であるが, 現状は用途を限定していたり, シス テムの永続性を考慮していない場合が多い. つまり, 入力 情報の面からは, 例えば圧密試験の全データがなければ圧 密沈下の詳細検討を行うことはできないし, システムの面 からは, 例えば汎用DBMSの使用は機種に限定されるため コンピュータの更新に伴ったシステムの再築や, パソコン の利用を制限することにもなる，しかし実際には，多種の 地盤調查情報をデータベース化するには極めて多くの人力 を必要とするため, 情報の使用頻度（重要度）と経済性 の面から入力情報の制約は当然あり, DBMSについても独 自に開発するには相当の労力と技能を必要とするため, 汎 用DBMSを用いたハード依存型のDBが構築される現状にあ る.

よって，地盤調査試験DBが果たすべき役割を将来的によ り広げるためには, (1)効率的に多種の地盤調査情報を蓄積 でき, (2)大型汎用機のみならずパソコン上でも活用できる, ハード非依存型のDBシステムを開発することが重要な課題 と考えられる.

\section{2 データベースの基本概念とシステム開発}

前述の様なDBシステムを開発するにあたっての留意点を 述べる，第 2 図にファイル処理とDB処理の違いを，第 3

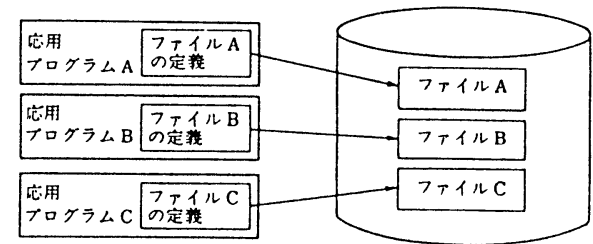

(a) ファイル処理

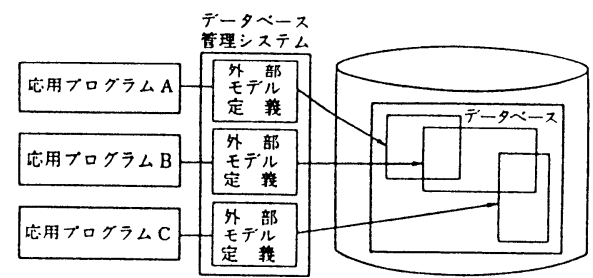

(b) データヘース処理

第 2 図 ファイル処理とデータベース処理 （諏訪・山本嘉・山本浩他, 1987 )

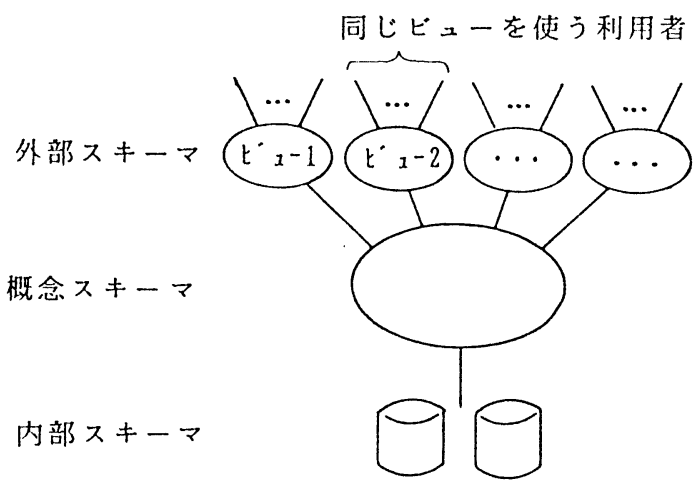

第 3 図 データベース・システムの三層構成法 ( 上林, 1984)

図にDBシステムの三層構成法を概念図で示す. 改めて述べ るまでもないが，DBシステムを独自に開発する場合には， この $2 つ の$ 概念を基としたシステム設計を行うことが重要 である。

DBとしての基本は, 応用プログラムから独立してデータ を管理・運用することにある。つまり, DB処理では, デー 夕量の増大やデータ項目の変更に対してファイルの一元的 な管理が行えるが, ファイル処理では, 応用プログラム個々 にファイルの定義や操作を行う必要がありファイル管理に 限界が生じる．これは，データの独立性を意味しており， その実現のために三層構成法の考え方がある。三層構成法 は, DBの構成を 3 つのスキーマ(あるいはモデル ), つ まりコンピュータ内部の物理的なスキーマ, DBの外部に位 置する応用プログラムや利用者の見方（ビュー）のスキー マ,ビューを包括した概念の論理的なスキーマに分割して データの独立性を達成する考え方である，この方法に限ら 
ず，データの独立性に対して自由度の高いシステム化が， DBシステムの開発に際して留意すべき点と考える.

ところで，地盤調查試験DBの特徵は，(1)扱うデータの 種類が多い，(2)用途が多様であり表示・解析機能の利用度 が高い，ことにある。それゆえ，地盤調查試験DBにおい てはデータの独立性を保つことが重要な課題であり, 高度 なシステム化が要求される。 しかしその反面, 地盤調查試 騃DBには「新たな地点の情報が追加されることはあるが, 一度入力された内容の更新は希であり, 主として読み出し 専用に用いられる」といら特徴も有すので，その開発には 当面オンライン更新に関する複雑な機能を付加する必要は ない，また，地盤調査圾騃DBでは応用プログラム（ AP : Application Program )に対する比重が大きいため, DBMS の操作言語（DML：Data Manipulation Language）にプ ログラミング言語の拡張として扱える親言語方式を採用し て，その開発に柔軟性を持たせる必要がある。

\section{4. データベース・システムの開発}

以上の構築理念を基として, 1982 年頃より地盤調査試験 DBシステムの開発に取り組んできた (岩崎・諏訪・山本他, 1984 ；岩崎・諏訪・山本，1984）。具体的には，(1)あら ゆる地盤調查情報のデータベース化，(2)機種に依存しない DBMSとAP，(3)FORTRANによるDML，(4)リレーショ ナルなデータ構造, (5)漢字処理など, の実現を基本思想と して, 汎用性の高いDBシステムの開発を目指した。

\section{1 地盤調查情報のモデル化と入カデータ}

地盤調查試験DBシステムの設計に際し，まず現実世界の 地盤調查情報を概念的にモデル化した，モデル化の方法は， 他のDBでも同様な考え方が採用されており，基本的には一 般化していると言える( 石井, 1985 ; 諏訪・山本嘉・山本 浩他, 1987 ).

一般に地盤調査情報は, 『調査地域 $\rightarrow$ 調查地点 $\rightarrow$ ( 地 層 一 ) 深度 一 圾験・検層データ』の順に情報がつながっ ている. この特性を利用すれば, ボーリング調査情報は次 の様に大別される.

(1) 調査に関する情報（ラベルデータ）

(2) 柱状図（地層, $N$ 值 ), サンプリング, 現位置試騃, 物理検層の各情報

（3）土質試験情報（物理試験，一軸試験， 三軸試験，圧密試験など）

各々は，地点毎あるいは地点一深度毎に一つにまとまる 組の集まりであり，(1)一(2)一(3)の階層順に関倸づけられる. 例えば, 地層情報は地層深度毎に土質名, 色調, 混入物 等が一組となり, 土質試験情報はサンプリング深度毎に各 試験データが一組となる。. よって, 地盤調查情報は, 複
数の組に分割でき，その各々は表の形で表現できる．この モデルで元のデータ構造を再現するには, 階層関係をたどっ て各表の結合を行えばよい，この形式は，関倸（リレー ショナル）モデルと呼ばれ，データの独立性やモデル作成 の容易さなどに優れていると言われている，当システムで は，この考え方に従って地盤調查情報を第 4 図に示す関係 表のつながりでモデル化した，図中において，枠で囲まれ た内容が一つの関係表を示しており, 各関係表の間には従 属関倸が階層づけられている。従属関係は，0３の 4 ラ ンクを設定した。 また，図中に㧊いて「一!」の印は， 新たな関倸表が追加可能な位置を示している.

第 1 表に，現時点での設定入力データを示す，表中に 招ける区分は, 前述の各関係表に対応しており, 各々の関 係表はハッチで示すデータ項目をキーとして結合される. また, 各表のデータ項目については, ほとんどのデータが 数值データであり值そのものに意味があるので, データベー ス化のための加工は行っていない，ただし，文字データの 内でAPが判別処理を必要とするデータ項目については加工 を行っている，例えば, 地層情報の土質・岩相名, 色調, 混入物，成状，地質年代はコード化を施している，その 手法は, 著者のひとりが土質について提案している方法を 採用したが（諏訪・山本・池森，1980），岩盤情報も一 体化するために，地層種別のコードを新たに加えた。 同コー ドは, 地層の種別〔土質, 堆積岩, 火成岩, 変成岩, 空洞をを示し，土質・岩相名のコードはその各々について 決められている.

なお，データの入力には，パソコンを使った対話形式に よる入力APを用いている. 対話形式による直接入力の方式 は，入力記録を残したり，誤入力への対応を工夫できるな どの利点がある.

\section{2 システムの構成}

第 5 図にシステム構成の概略を示す，当システムでは, 狭い地域を対象としたローカルDBと，それらを集積して集 中管理するためのホストDBの 2 種類を考えた.

ローカルDBは，主にパソコンの使用を想定し，データ の入力管理を行うDBとして位置づけた. 記憶媒体としては, フロッピーディスク (FD : Floppy Disk ) やハードディス ク（HD：Hard Disk）を用いる。 また，データ入力が途 中でもデータの参照が可能なシステム化を行い，地盤調查 管理など, データ入力とシステム動作が並行する場合にも 運用可能とした.

ホストDBは, ミニコンや大型コンピュータの使用を想定 し，大量データの検索に重点を置き，ローカルDBの集中 管理用のDBとした．記憶媒体としては，HDや光ディスク （OD：Optical Disk）を用いる。 ホストDBへのデータ入 


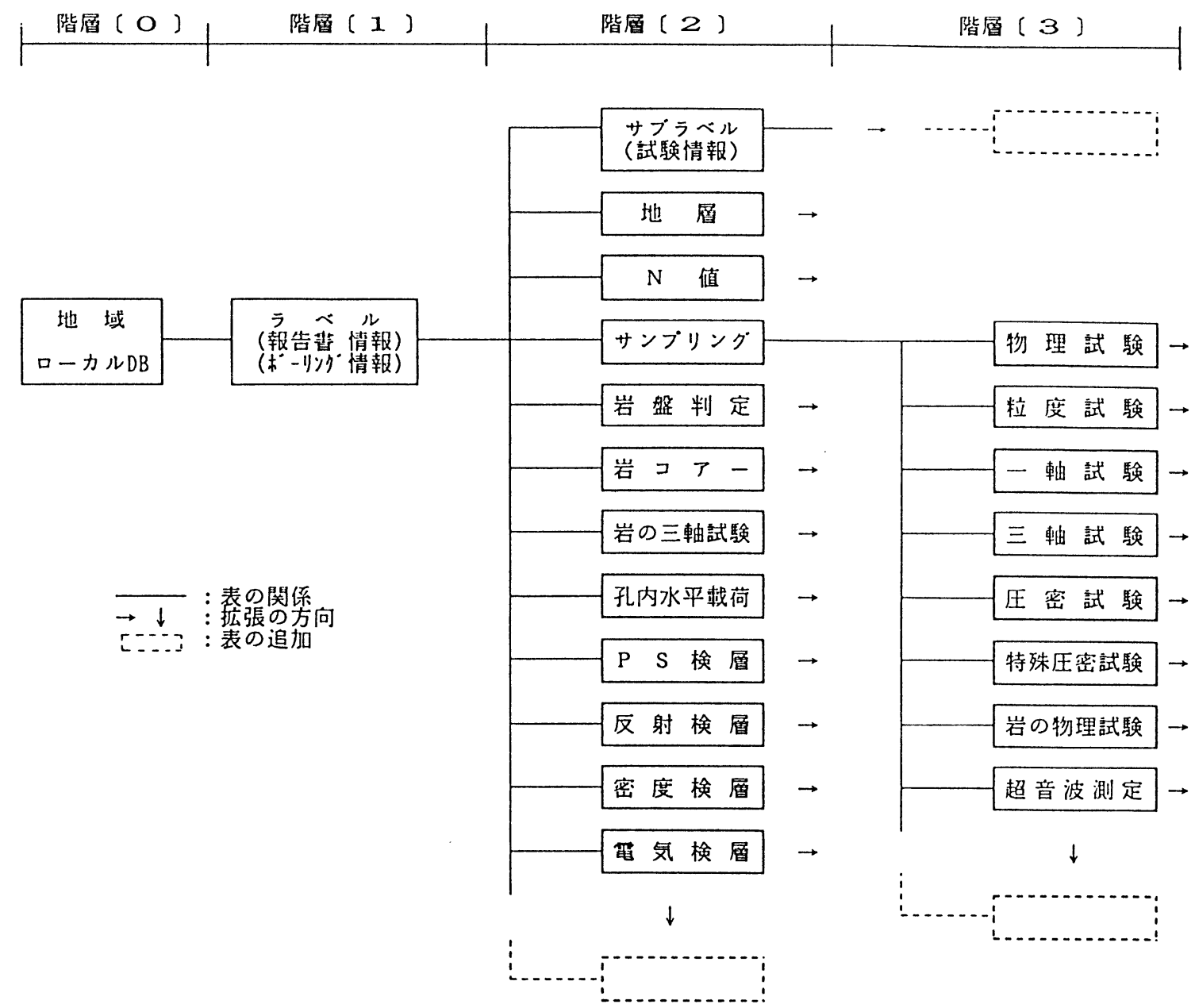

第 4 図 地盤調査情報のモデル化（関係表のつながり）

カは, ローカルDBをオフラインで転送・編集する形式を取っ た.

なお, 両者の記憶密度は, 調查長約 $30 \mathrm{~m}$ の標準的なボー リング調查で約 100 本 $/ 1 \mathrm{M}$ バイトである.

\section{3 ファイル構造とデータベース管理システム}

地盤調査試験DBにおいてデータの検索は, ボーリング単 位で行う場合が多く, データの抽出もボーリング毎に情報 を読み込む動作を繰り返し行う場合が多い，つまり，第 1 表のラベル・サブラベル情報のデータ項目から常に検索が 始まると限定すれば，ファイル操作は単純なものとなる. このことを満足するように, ファイル構造とDBMSを設計 した.

ファイルの構造は, ローカルDBでは 1 本のボーリング につき 1 個のデータファイルとし， ホストDBでは関係表 別にデータファイルを分割した. この他に, データファイ ル群の管理やデータ項目別の整列化を行うためのマネージ メントファイルを作成し, データの追加, 更新, 拡張が 関倸表ごとに独立して行えるように管理している. 例えば,

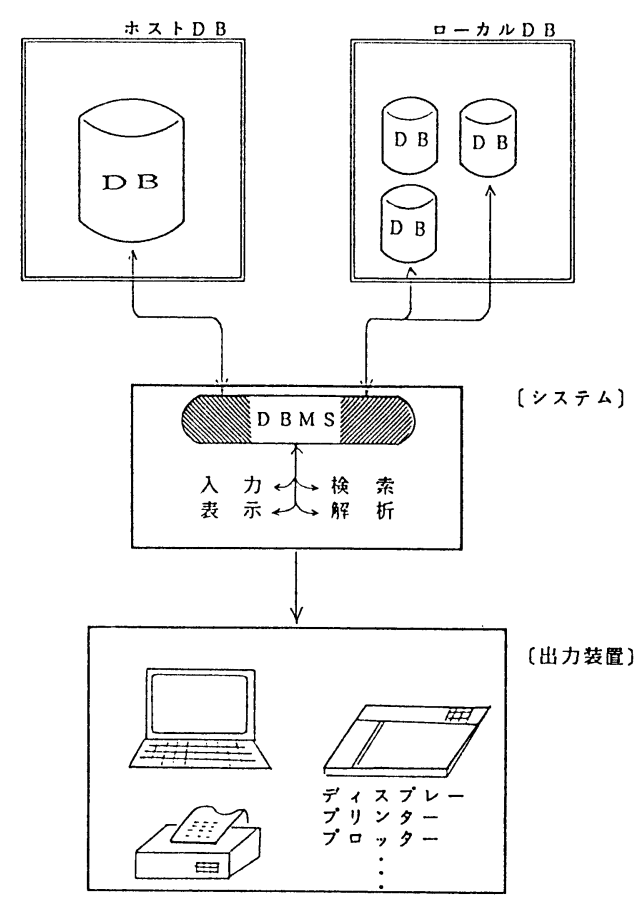

第 5 図 システム構成の概略 
第 1 表 データベースの入カデータ項目

\begin{tabular}{|c|c|c|}
\hline 階層 & テーブル名 & 項 \\
\hline $\mathrm{O}$ & 地域 & 地域 (ローカルDB)コート : ローカルD B タイトル, 登録年月日 \\
\hline 1 & ラベル & 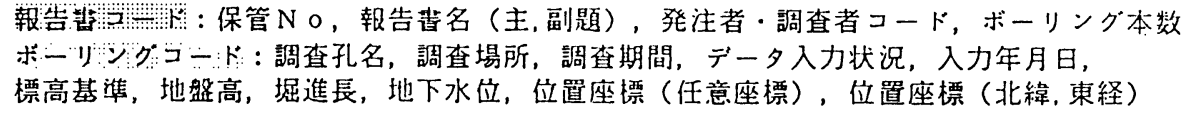 \\
\hline \multirow{12}{*}{2} & サブラベル & 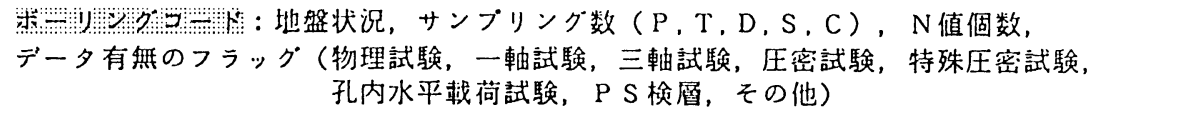 \\
\hline & 層 & 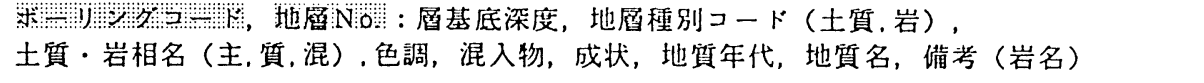 \\
\hline & 值 & 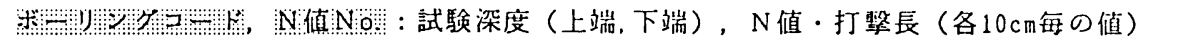 \\
\hline & サンプリング & 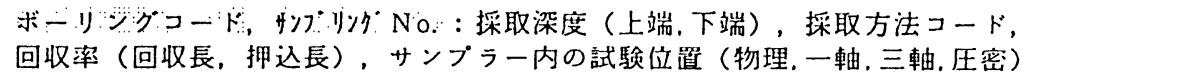 \\
\hline & 岩 盤 判 定 & 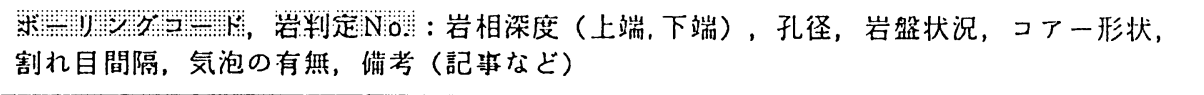 \\
\hline & 岩コア一 & 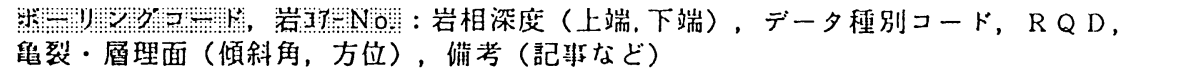 \\
\hline & 岩の三軸試験 & 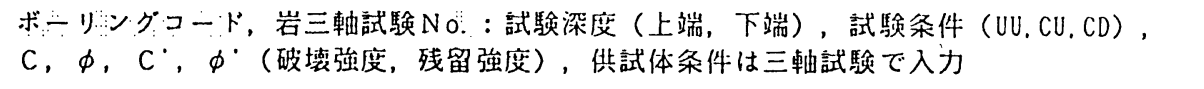 \\
\hline & 孔内水平輚荷 & 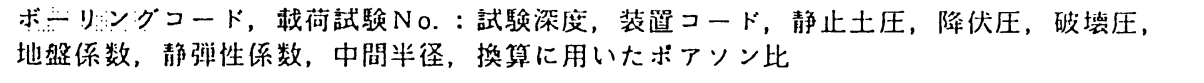 \\
\hline & $\mathrm{P} \mathrm{S}$ 検 層 & 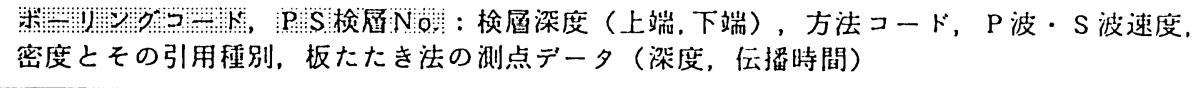 \\
\hline & 反射検層： & 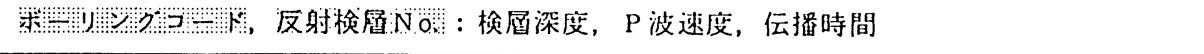 \\
\hline & 密度検層 & ボーリングコード, 密度檢層 No..：檢首深度, 密度 \\
\hline & 雪気検層 & 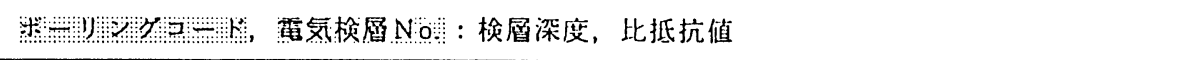 \\
\hline \multirow{8}{*}{3} & 物 理 試 験 & 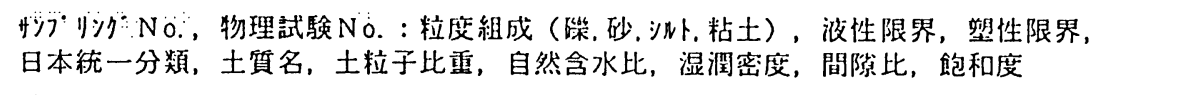 \\
\hline & 粒度試験 & 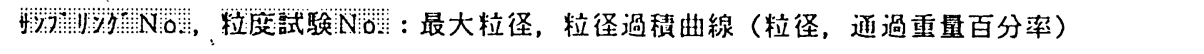 \\
\hline & 一 軸 試 験 & 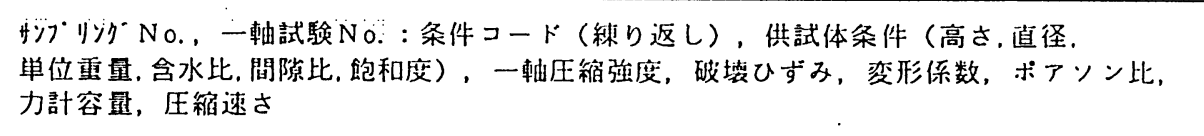 \\
\hline & 三軸 試 䮖 & 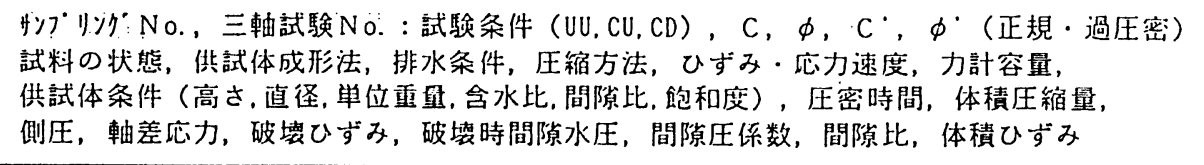 \\
\hline & 圧密試 験 & 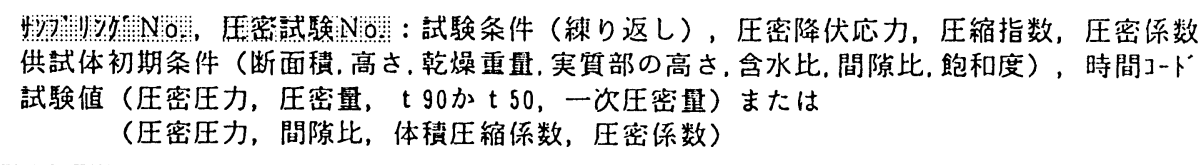 \\
\hline & 特殊圧密試験 & （多段階圧密，小戎荷圧密の試験データ） 内容は圧密試験に同じ \\
\hline & 岩の物理試験 & 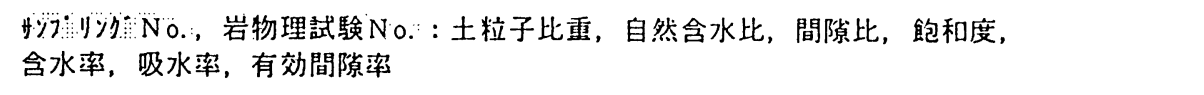 \\
\hline & 超音波測定 & 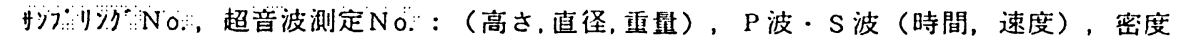 \\
\hline
\end{tabular}


ローカルDBのデータ入力においては, 関係表個々の登録と 入力は順不同であり（階層順は規制される），各表へデー タを追加入力することも時間的制約を受けない, なお, ロ一 カルDBでは， データファイルは文字列で書かれており，
即マスターファイルとして保存に供することができる.

また，DBMSは，データ入出力の管理に重点を置き，

種々の機能をライブラリーとしてパッケージ化した．この 方式は，機能性が悪いように思えるかもしれないが， AP

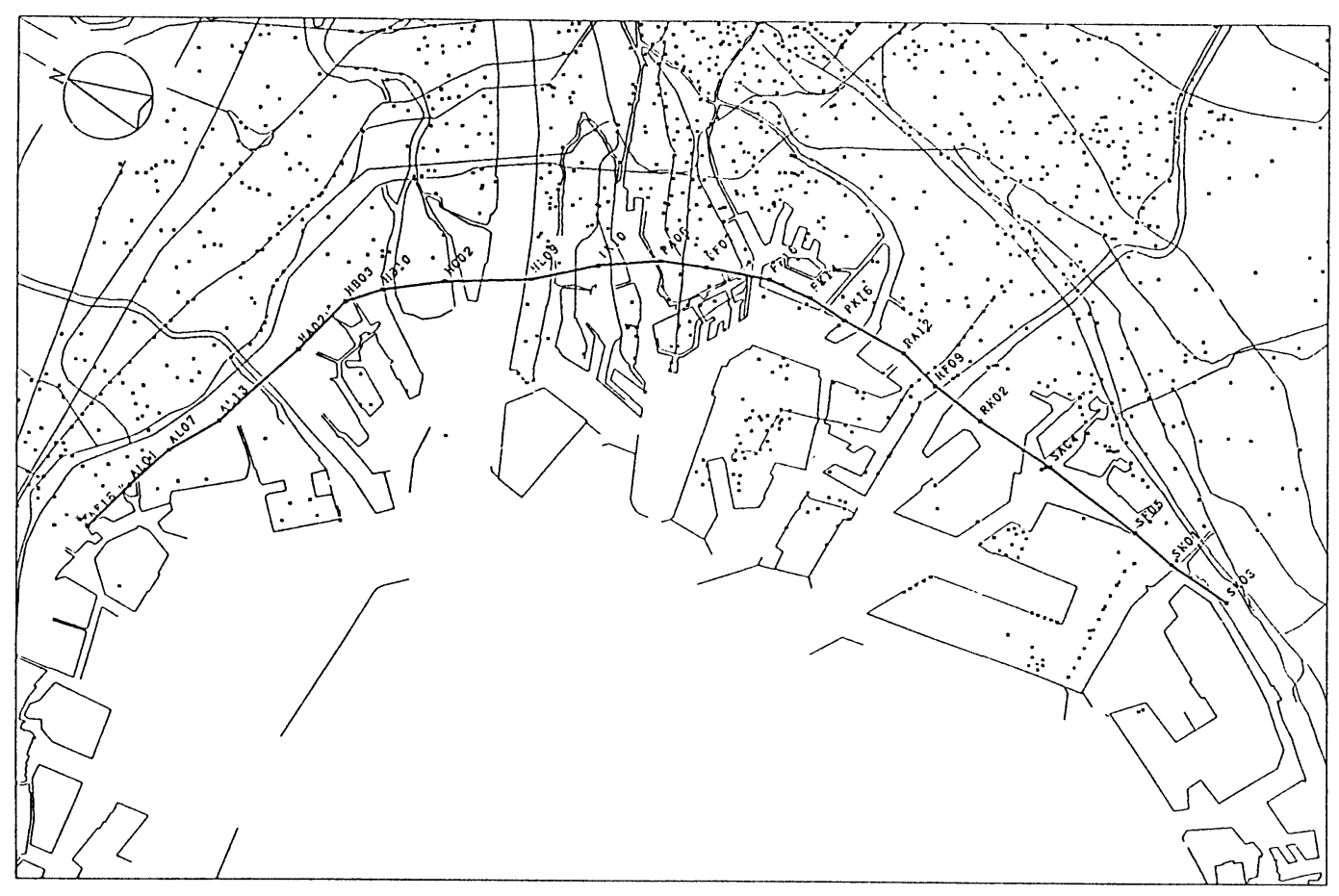

第 6 図（a） 断面線の検索表示例

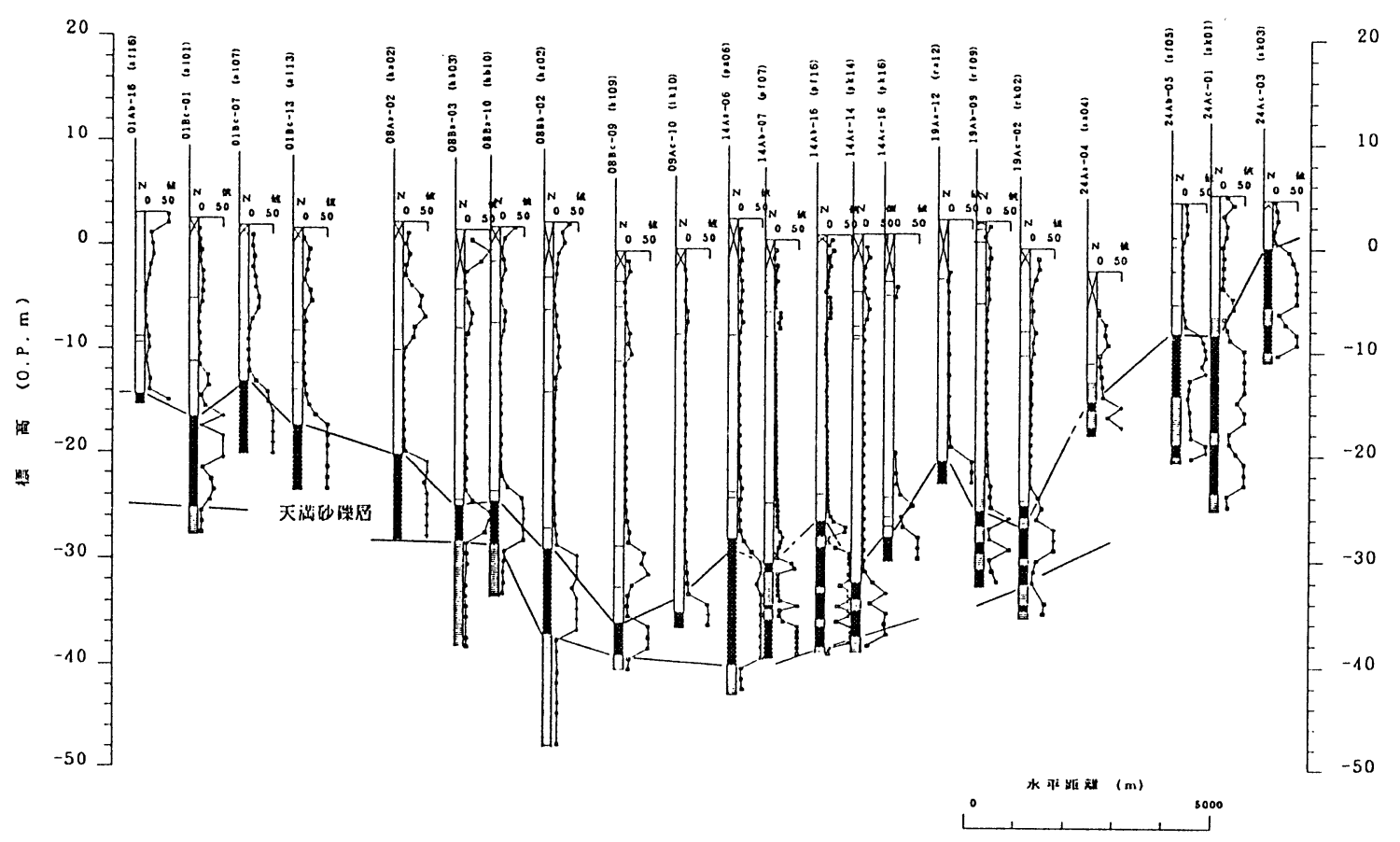

第 6 図（b） 地層断面図の出力例 


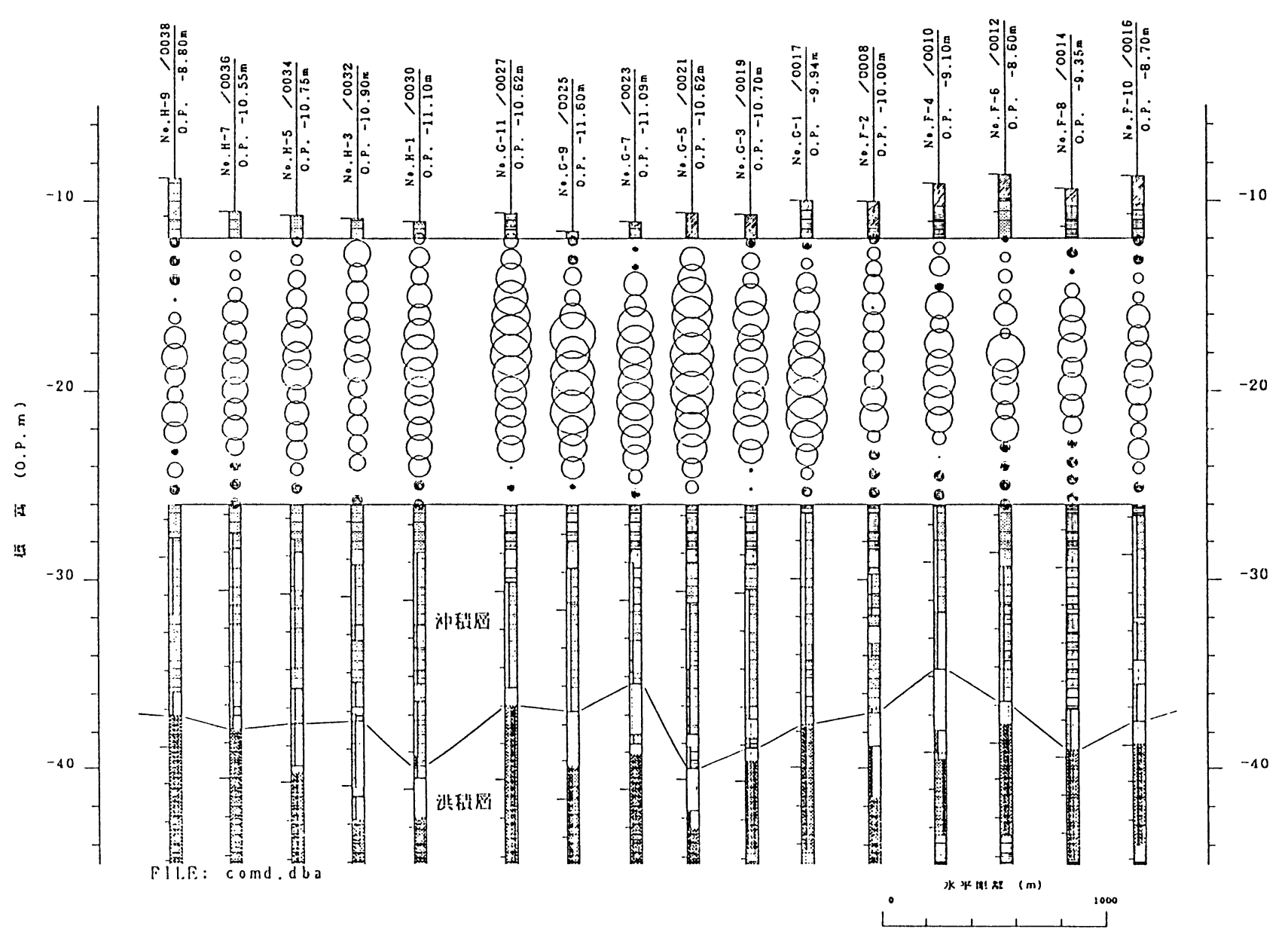

第 7 図 模式表示断面図の出力例

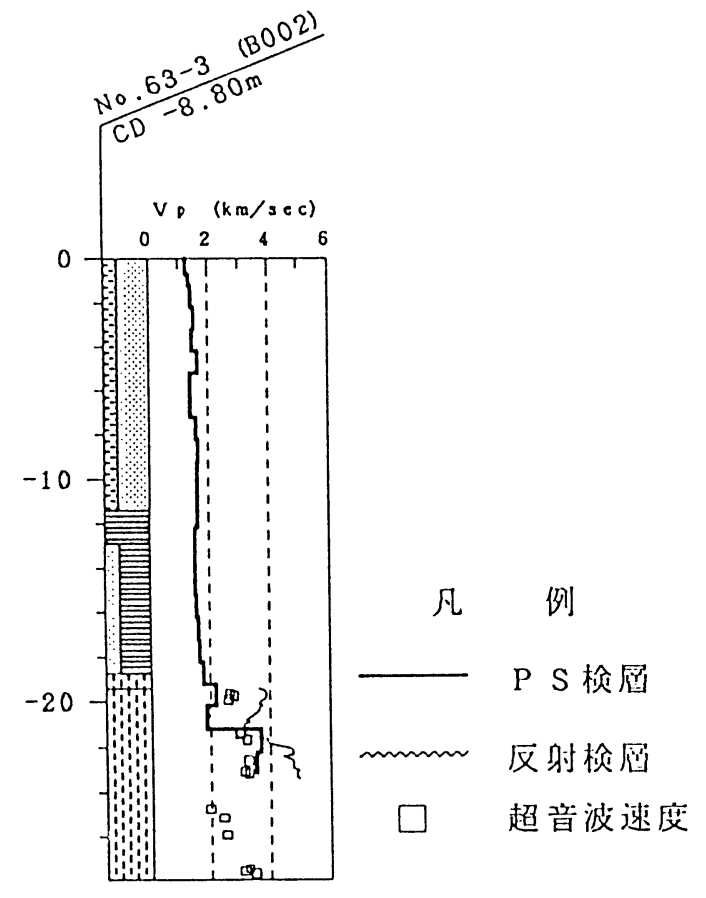

第 8 図 P波速度深度分布図の出力例

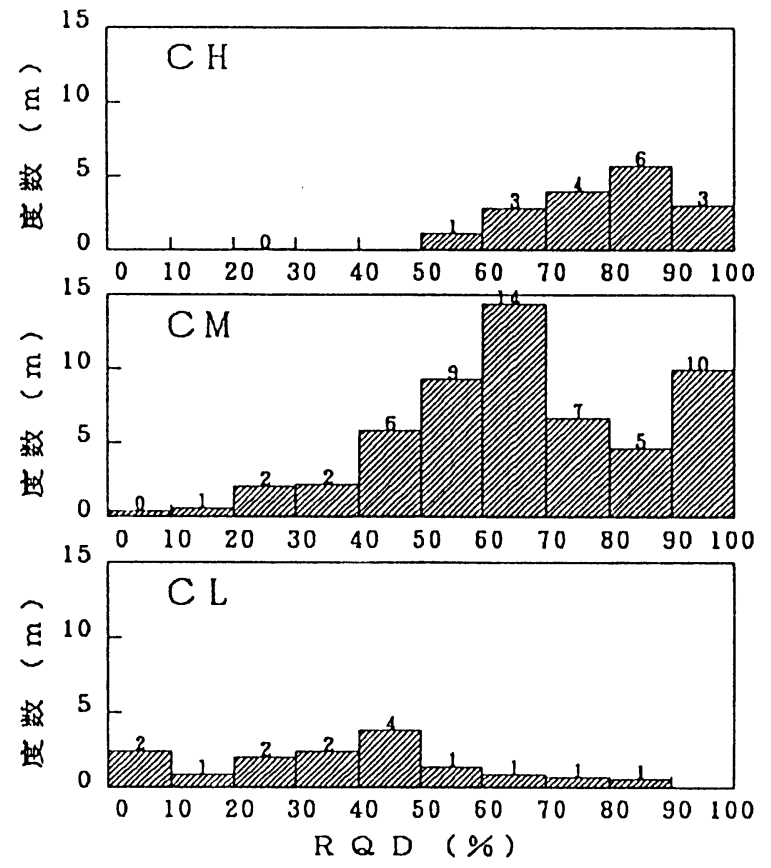

第 9 図 岩級別 $R Q D$ ヒストグラムの出力例
WL. OD

${ }_{125}$

0

O 105 


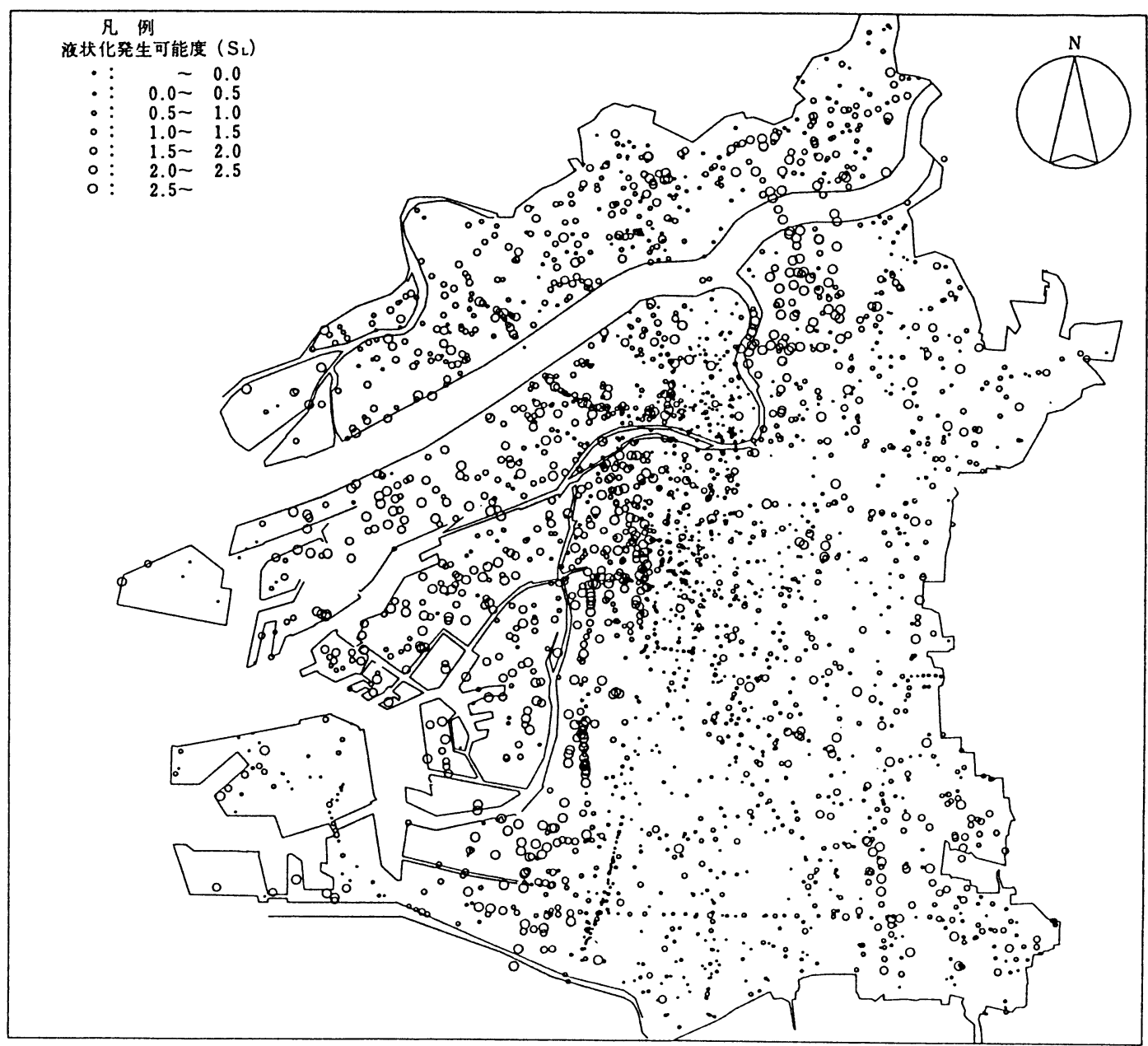

第 10 図上部沖積砂層の液状化難易度検討

に対する要求の多い地盤情報DBでは，種々のAPを開発す る際にDBMSからの制約が少ない方が柔軟性があって良い.

\section{4 応用例}

現在，本システムには，対話形式によるデータ入力， 位置図などによるボーリング検索, リスト・テキストファ イル出力, 基本的な図化出力（断面図, 深度図, 相関図, 圧密関係図, 物性值模式表示図など), 基本統計処理など のAPを備えている，以下では，基本的な図化出力の例を 示す.

第 6 図は大阪平野で実施されたボーリングを用いて沿岸 にそった断面図を作成した例である，DBでは位置図（a） の上で自由に断面を指定することができる．第 7 図は海底 地盤沖積粘土層の液性限界 $\left(W_{L}\right)$ を模式的に表示した例 である. 同じ地層でも土質工学的性質は地域的に差がある 場合が多く，DBを用いればその特性を視覚的に把握する ことも容易である。また，第 8，9図には，孔内検層や 室内試験のP波速度を土層図に併記した例, 岩級別の $R Q D$

( Rock Quality Designation )をヒストグラムで図化した
例を各々示した。

また，当システムを開発する過程において，いくつか の応用的な活用を行った。第 10 図は，大阪市域の約 3 , 600 本のボーリングデータを用いて液状化の難易度判定を 行った結果である（柴田・岩崎・誀訪・山本, 1987 ). 液状化検討には岩崎 - 龍岡の方法を用い, 液状化発生可能 度を定義し, 地点毎の液状化難易度を円の大きさで模式的 に表示した。

この他, 海底地盤における土質工学的性質の地域性検討 にも運用を行った（菊田・渡辺・岩崎, 1984 ; 木山・諏 訪・山本浩, 1987 ; 中世古・諏訪他, 1987 ).

\section{5. おわりに}

建設全般への利用を目的とした地盤情報DBの構築におい ては, その核となる地盤調査情報を詳細にデータベース化 することが，その実現に向けての第一歩となる，開発を 行った地盤調查試験DBシステムは，超軟弱な地盤から岩 盤までの地盤調査データを処理でき, 新たな情報に対して も処理領域を拡張することができる，また, DMLにFOR- 
TRANを使用しているのでAPの作成が容易である.

現在, 当所では, 当システムを地盤調査管理, 設計デー 夕の整理, 地盤特性解析, 都市防災に関する検討などに 運用している. 今後の課題として，マッピングシステム との融合, 三次元表示の実現, 設計支援システムとの連 結・運用などの研究を進めている.

文
石井一郎（1985） 土質データベースシステムの開発に

ついて. 運輸省港湾技術研究所港湾技研資料, No.515. 石村賢二・中山俊雄（1986） 地盤情報システムにおけ る地質柱状図データベース化. 昭和 61 年度東京都土木 技術研究所年報， 259-266.

岩崎好規・諏訪靖二・山本浩司・安永文夫・福田光治 (1984) リレーショナル・データベースとしての地盤情報とその 応用. 第 19 回土質工学研究発表会, 7-8. 岩崎好規・諏訪靖二・山本浩司（1984）地盤情報のデー タベース化とその応用. 第 9 回電算機利用に関するシ ンポジウム, 土木学会・土木情報システム委員会, 113ー 116

岩崎好規・諏訪靖二・山本浩司（1989）地盤情報デー タベースの構築理念と汎用システムの開発. 第 34 回土 質工学シンポジウム, 土質工学会, 195-202.

上林弥彦（1984） データベース・システムの基礎, bit 別冊最近のデータベース・システムとその応用. 共立出 版， $16-37$.

風間秀彦・岩崎公俊・堀井克巳（1989）地盤情報デー タベースの現状と問題. 土と基礎， 37, No.1， 1116.

㐘田升三 - 渡辺具能 - 岩崎好規（1984）広島湾海底地 盤の地盤工学的性質について, 地盤と建設, 土質工学 会中国支部， 2, No.1，1-12.

幾志新吉・菅原正巳・清水良作（1971） 電算機による 都市地盤土質柱状図資料の一検索法（第一報）。土と
基礎，99， No.4， 23-30.

木山正明・諏訪靖二・山本浩司（1987） 大阪港海底粘 土の土質工学的性質について. 海底地盤に関するシポジ ウム, 土質工学会関西支部・大阪湾海底の地盤研究委員 会, $139-144$.

柴田 徹・岩崎好規・諏訪靖二・山本浩司（1987） ボー リングデータベースによる大阪地盤の液状化ポテンシャ ルゾーニング. 都市防災シンポジウム講演集, 土木学 会関西支部, 87-92.

諏訪靖二・山本嘉一郎・池森珪祐（1980） 土質調査管 理システム（SOIL）について. 第 15 回土質工学研 究発表会, 1-4.

諏訪靖二 - 山本嘉一郎・山本浩司・森島和也・荒木繁幸・ 伊藤信一・小野 諭・藤原重彦（1987） 新編大阪地 盤図，第 5 章地盤情報のデータベース化. 土質工学会 関西支部・地質調査業協会編，コロナ社，65-79.

東京都土木技術研究所（1987） 東京低地の液状化予測. 東京都

中世古幸次郎 - 福代倫男 - 関塚良光 - 来馬章雄 - 木山正明 -

脇 茂行・田村健一郎・野口秀喜・諏訪靖二（1987）

大阪湾海底地盤の地質特性と土質工学的性質について. 海底地盤に関するシンポジウム, 土質工学会関西支部・ 大阪湾海底の地盤研究委員会, $21-48$.

日本建設情報総合センター（1989）建設情報データベー ス JACIC NET。 JACIC情報， 4, No.1， p.101。 山本浩司・諏訪靖二・山本嘉一郎（1987） 汎用DBMS を用いたパーソナルコンピュータによる地盤情報データ ベースの作成. 土木学会第 42 回年次学術講演会, 第 3 部, 640-641.

吉川宗治・岩崎好規・田居 優（1987） 大阪地域の地震 防災とボーリングデータベースによる大阪地盤のサイス ミックゾーニング. 都市防災シンポジウム講演集, 土 木学会関西支部, 81-86. 


\section{要 旨}

地域地盤地質情報に対する地盤工学データベース・システムの開発と構築理念

: 岩崎好規・諏訪靖二・山本浩司

パソコンレベルのコンピューターによる各種データの処理能力が向上し, それらを比較的容易に利用 できるようになった現在, ボーリング柱状図を初めとする地盤情報のデータベース化が各機関において 行われている.（財）大阪土質試験所においては，地域地盤情報の特性のデータベース化に当たって， 次のようなシステム開発を目指した。

(1) 軟弱地盤から岩盤までのす心゙ての地質地盤に適応できること.

(2) 柱状図データのみならず, 室内土質試験, 現位置試験結果も広範囲に取り入れること.

(3) 地域地盤の特性の比較や抽出が容易にできるリレーショナル型のデータベースを構築すること.

(4) 数年でハードが変革している現在, 機種によらないハードインデペンデントなコンピューター作業 環境を実現すること．

(5) パソコンや大型コンピューターとの効率的かつ有機的な統合利用のために, 主として入力用に独立 に作動するパソコンレベル用のローカルシステム，さらにそれらを集積して管理するホストシス テムの 2 システムで構成すること.

キーワード : データベース, 地域地盤, 地盤情報, ボーリング 